\title{
Performance Analysis of a Photovoltaic-Thermal Integrated System
}

\author{
Ewa Radziemska \\ Chemical Faculty, Gdansk University of Technology, 80-233 Gdansk, Poland \\ Correspondence should be addressed to Ewa Radziemska, ewarad@chem.pg.gda.pl
}

Received 19 November 2008; Revised 24 February 2009; Accepted 21 April 2009

Recommended by Raghu N. Bhattacharya

\begin{abstract}
The present commercial photovoltaic solar cells (PV) converts solar energy into electricity with a relatively low efficiency, less than $20 \%$. More than $80 \%$ of the absorbed solar energy is dumped to the surroundings again after photovoltaic conversion. Hybrid $\mathrm{PV} / \mathrm{T}$ systems consist of PV modules coupled with the heat extraction devices. The PV/T collectors generate electric power and heat simultaneously. Stabilizing temperature of photovoltaic modules at low level is higly desirable to obtain efficiency increase. The total efficiency of $60-80 \%$ can be achieved with the whole PV/T system provided that the T system is operated near ambient temperature. The value of the low-T heat energy is typically much smaller than the value of the PV electricity. The PV/T systems can exist in many designs, but the most common models are with the use of water or air as a working fuid. Efficiency is the most valuable parameter for the economic analysis. It has substantial meaning in the case of installations with great nominal power, as air-cooled Building Integrated Photovoltaic Systems (BIPV). In this paper the performance analysis of a hybrid PV/T system is presented: an energetic analysis as well as an exergetic analysis. Exergy is always destroyed when a process involves a temperature change. This destruction is proportional to the entropy increase of the system together with its surroundings-the destroyed exergy has been called anergy. Exergy analysis identifies the location, the magnitude, and the sources of thermodynamic inefficiences in a system. This information, which cannot be provided by other means (e.g., an energy analysis), is very useful for the improvement and cost-effictiveness of the system. Calculations were carried out for the tested water-cooled ASE-100-DGL-SM Solarwatt module.
\end{abstract}

Copyright ( 2009 Ewa Radziemska. This is an open access article distributed under the Creative Commons Attribution License, which permits unrestricted use, distribution, and reproduction in any medium, provided the original work is properly cited.

\section{Introduction}

Over $80 \%$ of the world solar cell and module production is currently based on sliced single crystal and polycrystalline silicon cells, so this paper is focused on the silicon.

Applications of solar energy can be broadly classified into two categories: thermal systems (T) that convert solar energy into thermal energy and photovoltaic systems (PV) that convert solar energy directly into electrical energy. The vital component for the above conversion is the solar energy collection system. Usually these systems (T) or (PV) are used alone. A hybrid PV/T system, which is also known as a photovoltaic-thermal system, generates both thermal and electrical energy simultaneously.

The photovoltaic efficiency of solar cells is temperature dependent and it decreases with the increasing temperature (Figure 1) due to the worse mobility of carriers, diffusion length, as well as lifetime of minority carriers and saturation current. Silicon photovoltaic cells are good absorbers, so their temperature rises during operation significantly.

$\mathrm{PV} / \mathrm{T}$ concept offers an opportunity to increase overall efficiency by making use of waste heat generated in the PV module.

The major phenomena that limit PV efficiency of the module are as follows

(i) light reflection from the module surface,

(ii) solar light energy too little or too much of that which is needed to separate electrons from bonds,

(iii) recombination of electrons and holes before they could contribute to electric current,

(iv) series resistance to current flow,

(v) self-shading resulting from top-surface electric contacts, 


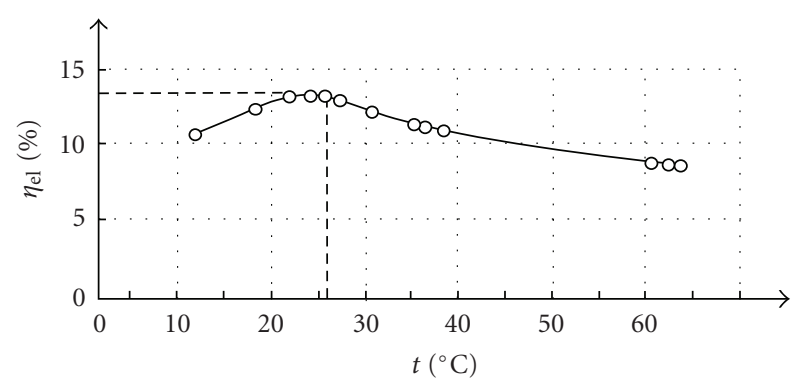

Figure 1: The photovoltaic efficiency of the silicon solar cells/modules in the function of temperature.

(vi) performance degradation at nonoptimal operating temperatures.

Due to the absorption of electromagnetic radiation also the heat is produced by a solar module. Apart from heating, radiation entering a solar cell can set free electrons from its atomic bond creating electron-hole pairs. In order to generate the electron-hole pair, the sufficient photon energy must be provident to the cell, at least equal to the material band-gap energy. Then, by means of a built-in potential barrier of the $\mathrm{p}-\mathrm{n}$ junction the electrons are separated from holes, generating a photoelectric current, Joule's heat in the series resistance of the module, and electric power in the load circuit as well. A temperature increase above $25^{\circ} \mathrm{C}$ degrades significantly $U_{\text {oc }}$ and output power and conversion efficiency of a silicon solar module (often power loss is equal to $0.5 \% / \mathrm{K}$ ). In order to diminish this effect, it is useful to decrease the module temperature by removing the heat.

The temperature of the module can be calculated on the base of the NOCT (nominal operating temperature) value:

$$
t_{m}=t_{a}+(\mathrm{NOCT}-20) \cdot \frac{E}{800}
$$

where NOCT is defined as the module temperature in standard reference environment (SRE), defined as follows: solar irradiation $800 \mathrm{~W} / \mathrm{m}^{2}$, ambient temperature $20^{\circ} \mathrm{C}$ and wind velocity $1 \mathrm{~m} / \mathrm{s}$. NOCT is determined on the base of International Standard EN-61215 for the modules without load.

To reduce the module temperature an air-cooling or water-cooling of a flat plate collector is used in a hybrid PV/T system (Figure 2). The material used to paste the cells on the absorber plate is a good thermal conductor and a good electrical insulator. The temperature of cooling medium increases linearly by the output port.

Garg and Agarwal [1] presented the first simulation study of the PV/T air-cooling flat plate collector. Prakash [2] and Sopian et al. [3] conducted these types of simulation studies. Sopian analyzed the performance of a single-pass and double-pass hybrid PV/T collector. In this configuration, the air at first enters the flow channel formed by the glass cover and the upper metallic collector, and then under it. In consequence, this flow arrangement effects greater heat removal from the top absorber plate and reduces the heat loss from the collector. Metallic plates are painted

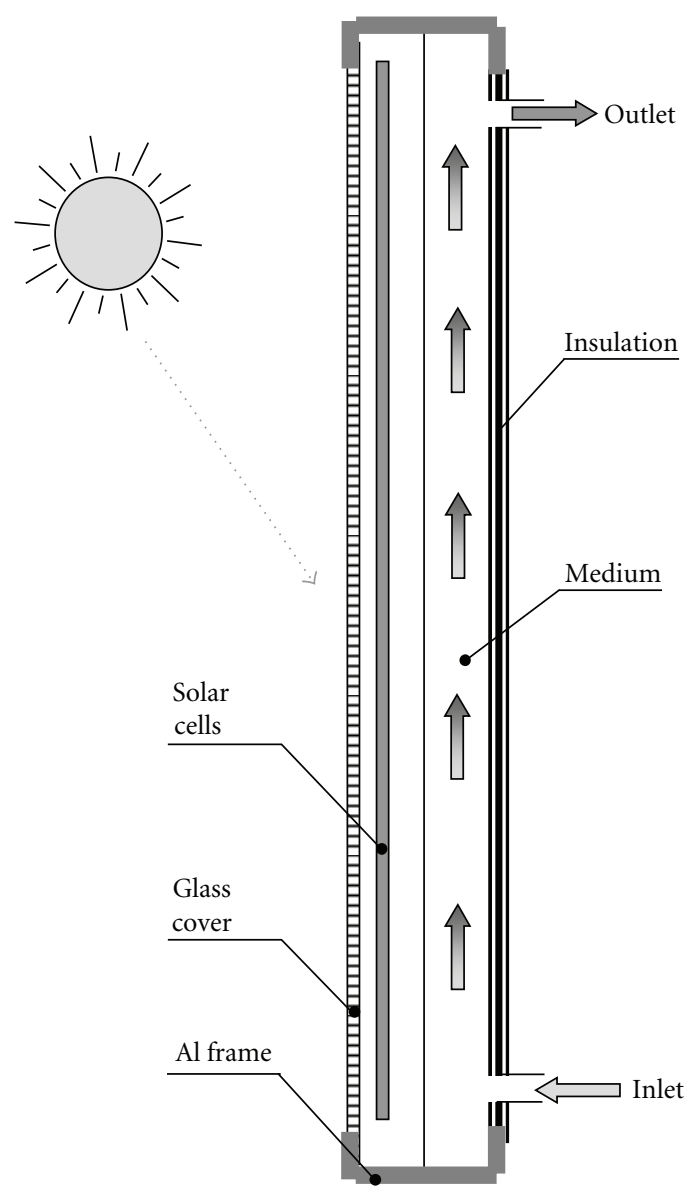

FIgUre 2: PV/T system concept.

black and the PV cells are pasted over the upper plate. To protect the cells from the contact with the air flow, the cells are covered; otherwise the cells would be damaged. A protective transparent layer is applied to the cell surfaces. The possibility of generating electricity and heat energy from a commercial PV module adopted as a PVT/AIR solar collector with either forced or natural airflow in the channel was demonstrated by Tonui and Tripanagnostopoulos [4].

The electrical power output of a PV/T solar system is a function of incident irradiance and the module temperature. The power output depends not only on the intensity of the incident radiation, but also on the spectral content and the electrical operating point of the module.

The electrical efficiency $\eta_{\mathrm{el}}$ of the crystalline silicon (c-Si) solar cells/modules is given as a function of temperature:

$$
\eta_{\mathrm{el}}=\eta_{0}\left[1+\beta\left(T_{\text {cell }}-298 \mathrm{~K}\right)\right]
$$

with $\eta_{0}$-efficiency of the module at temperature of $298 \mathrm{~K}$.

Silicon efficiency temperature coefficient is equal to $\beta=$ $-6,3 \cdot 10^{-3} \mathrm{~K}^{-1}[4], \beta=-4,5 \cdot 10^{-3} \mathrm{~K}^{-1}[5], \beta=-6,4$. $10^{-3} \mathrm{~K}^{-1}[6]$, or $\beta=-8 \cdot 10^{-3} \mathrm{~K}^{-1}$ [7].

For amorphous silicon (a-Si) cells, the effect is less, with decrease of about $0.25 \%$ per degree rise in temperature depending on the module design and length of the outdoor exposure [8]. 


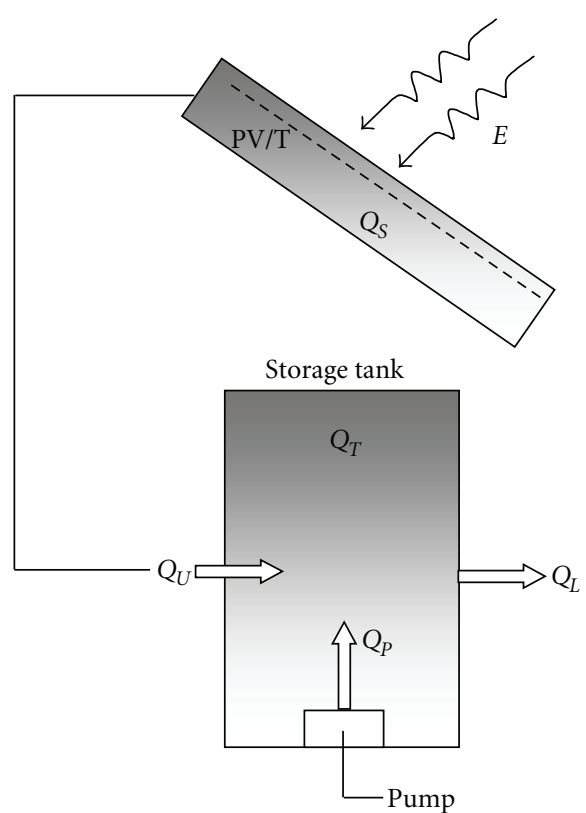

FIgure 3: The energy flow in the system.

The heat can be drawn from the cells due to the conduction, convection, and radiation. The heat drawn from the modules during operation may be utilized in various applications.

During the operation of the PV/T system the measured parameters include irradiance $E$, storage tank temperature $T_{i}$, PV cells temperatures $T_{\text {cell }}$, ambient air temperature $T_{a}$, and absorber plate temperature $T_{2}$.

PV/T thermal efficiency of the collector, $\eta_{T}$, including stored specific heat, can be obtained from system energy flow analysis, giving (Figure 3 )

$$
\eta_{T}=\frac{Q_{U}+Q_{S}}{E \cdot S}=\frac{Q_{T}+Q_{L}-Q_{P}+Q_{S}}{E \cdot S},
$$

where $S$ is the heat absorber plate surface area, $Q_{T}$ is the total heat collected in the storage tank, $Q_{P}$ is the constant heat input from a circulation pump mounted in the storage tank, $Q_{U}$ is the useful energy gain delivered by the collector to the storage tank, and $Q_{S}$ is the energy amount stored as specific heat in the collector plate.

The heat loss from the tank to the surrounding can be calculated as

$$
Q_{L}=\int(U S)_{\operatorname{tank}}\left(T_{i}-T_{a}\right) d T,
$$

where (US $)_{\text {tank }}$ is the a heat transfer coefficient for the storage $\tan k$ and $U_{L}$ is the collector overall heat loss coefficient.

The total thermal energy stored in the fluid (water) [9]

$$
Q_{T}=Q_{U}-Q_{L}+Q_{P}
$$

There are three possible methods of thermodynamic analysis for system which produces electric and heat energy simultanously:

(i) energetic efficiency analysis,

(ii) energy-saving efficiency,

(iii) exergetic efficiency analysis,

conducted on the base of the obtained electrical output power and heat flux.

In German company PVTWINS-for the photovoltaic module $1.0 \mathrm{~m} \cdot 1.9 \mathrm{~m}$ with water collector- $150 \mathrm{~W}$ of electric power and $765 \mathrm{~W}$ of heat flux in STC conditions (solar irradiance $E=1000 \mathrm{~W} / \mathrm{m}^{2}$, solar reference spectrum AM 1.5, cell temperature $t_{\text {cell }}=25^{\circ} \mathrm{C}$ ) conditions have been obtained [10]. In the same conditions for system of water-cooled ASE100-DGL-SM Solarwatt module (Table 1) with the surface of $0.88 \mathrm{~m}^{2}$ the amount of $79.6 \mathrm{~W}$ of electric power and the heat flux equal to $465 \mathrm{~W}$ were obtained.

\section{The Energetic Conversion Efficiency Analysis}

Many researchers used an overall energetic efficiency for evaluating the PV/T systems. A total efficiency of $60-80 \%$ can be achieved in this manner $([11,12])$.

Introducing the fill factor (FF), defined for the characteristic of solar cell/module as

$$
\mathrm{FF}=\frac{P_{\max }}{I_{\mathrm{sc}} U_{\mathrm{oc}}},
$$

the photovoltaic conversion efficiency is given as

$$
\eta_{\mathrm{el}}=(\mathrm{FF}) \frac{I_{\mathrm{sc}} U_{\mathrm{oc}}}{E \cdot S}
$$

with $P_{\max }$ is the maximum generated power, $I_{\mathrm{sc}}$ is the short circuit current, $U_{\mathrm{oc}}$ is the open cell voltage, $S$ is the surface of the unit, and the thermal efficiency of the heat collector:

$$
\eta_{T}=\frac{c_{p} \cdot \dot{m}_{\mathrm{av}}\left(T_{\mathrm{out}}-T_{\mathrm{in}}\right)}{E \cdot S},
$$

where $\dot{m}_{\mathrm{av}}$ is an average flux of the fluid and $c_{p}$ is the specific heat of working fluid.

The energetic conversion efficiency of the integrated $\mathrm{PV} / \mathrm{T}$ system $[12,13]$ is

$$
\eta_{\mathrm{PV} / \mathrm{T}}=\frac{W+Q}{H}=\eta_{\mathrm{el}}+\eta_{T},
$$

where $W$ is the mechanical work or electricity produced, $Q$ is the thermal energy in delivered steam or other medium, and $H$ is the input energy.

For specific use, the quantities of "heat" (usually an enthalpy difference) and electricity or work have to be defined precisely. The ratios $\eta_{\mathrm{el}}=W / H$ and $\eta_{T}=\mathrm{Q} / H$ are, respectively, called electric efficiency and heat efficiency.

Calculated in this manner the energetic conversion efficiency for the tested water-cooled ASE-100-DGL-SM Solarwatt module is equal to $65.8 \%$. 
TABLE 1: Parameters of the ASE-100-DGL-SM module without cooling [7].

\begin{tabular}{lccccc}
\hline & $U_{\mathrm{oc}}(\mathrm{V})$ & $I_{\mathrm{ph}}(\mathrm{A})$ & $P_{\max }(\mathrm{W})$ & $\mathrm{FF}$ & $\eta_{\mathrm{el}}(\%)$ \\
\hline$t=25^{\circ} \mathrm{C}$ & 42.18 & 2.545 & 79.60 & 0.724 & 13.3 \\
$t=60^{\circ} \mathrm{C}$ & 34.75 & 2.555 & 61.28 & 0.690 & 10.3 \\
\hline
\end{tabular}

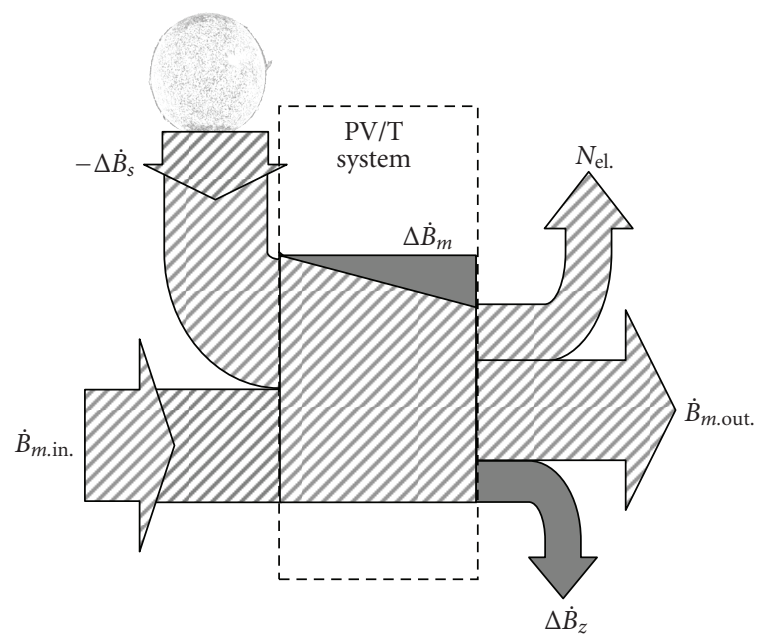

FIgURE 4: The exergy fluxes flow in PV/T system.

\section{Energy-Saving Efficiency}

The value of electric power and thermal energy differs due to the form of energy. To correctly evaluate the energy saving of PV/T system, Huang et al. [14] defined the energy-saving efficiency, in terms of the primary-energy saving as

$$
E_{f}=\frac{\eta_{\mathrm{el}}}{\eta_{\text {power }}}+\eta_{T}
$$

where $\eta_{\mathrm{el}}$ is the electric power generation efficiency for PV modules, $\eta_{\text {power }}$ is the electric power generation efficiency for a conventional power plant, and $\eta_{T}$ is the heat collection efficiency of the system.

As $\eta_{\text {power }}$ is usually equal to about $40 \%$, the overall efficiency of the PV/T system will be greater than that defined by (9), because 2.5 will multiply the photovoltaic component.

Calculated in this manner energy-saving efficiency for the tested water-cooled ASE-100-DGL-SM Solarwatt module is significantly greater than energetic efficiency and is equal $85.3 \%$. Huang et al. [14] expected that the primary energysaving efficiency $E_{f}$ for a PV/T system should exceed 0.50 in order to compete with a pure solar hot water system. For the tested PV/T system with ASE module this improvement is equal to 0.61 .

\section{Exergy Analysis}

The exergy efficiency can be defined to describe the quality difference between electricity and heat.

The exergy of a thermodynamic system is the maximum work that can be done by the system when it undergoes reversible processes that bring the system into complete thermodynamic equilibrium with a defined reference environment. The exergy $B$ of a system with respect to a reservoir is the maximum work done by the system during a transformation which brings it into equilibrium with the reservoir. Reservoir in practice is the surrounding with high capacity for receiving heat. Energy that has a high convertibility potential is said to contain a high share of exergy. Electricity and mechanical work are perfectly convertible and for these forms exergy contents equals the energy content. Reversely, heat at temperature close to the reservoir has low convertibility potential; the exergy content of such heat is much lower than its energy content.

The total exergy of a system consists of [15] the following

(i) physical energy, due to the deviation of the temperature and pressure of the system from those of the environment,

(ii) chemical exergy, due to the deviation of the chemical composition of the system from that of the environment,

(iii) kinetic exergy, due to the system velocity measured relative to the environment,

(iv) potential exergy, due to the system height measured relative to the environment.

Exergy analysis is used in the field of industrial ecology as a tool to both decrease the amount of exergy required for a process and use available exergy more efficiently. Using the concept of exergy, technical processes such as cogeneration are readily described. In cogeneration, part of the energy is converted to work or electricity with high exergy content, and the remaining heat is used for purposes where moderate temperature (lower exergy content) is useful, such as food processing, drying, and space heating.

As the electric energy has the same status as the heat energy from the source in the form of body with infinite temperature, it leads to possibility of specifying the relative energy flux by means of exergetic analysis [16].

The exergetic fluxes flow for the PV/T systems is illustrated in (Figure 4).

Exergetic efficiency for the PV/T system is defined as

$$
\varepsilon=\frac{N_{\mathrm{el}}+\Delta \dot{B}_{\mathrm{cm}}}{N_{\mathrm{irr}}}=\frac{N_{\mathrm{el}}+\dot{m} \Delta b_{\mathrm{cm}}}{E \cdot S} .
$$

For bodies with constant heat capacity, exergy variation is equal to physical exergy variation and then

$$
\Delta b_{\mathrm{cm}}=\Delta b_{f}=c_{p}\left(T-T_{a}-T_{a} \cdot \ln \frac{T}{T_{a}}\right),
$$

where $b_{\mathrm{cm}}$ is the specific exergy of the cooling medium, $T_{a}$ is ambient temperature. 
In the case, when water is heated in the PV/T system from $10^{\circ} \mathrm{C}$ to $25^{\circ} \mathrm{C}$ one can obtain $\Delta b_{w}=\Delta b_{f}=176.75 \mathrm{~J} / \mathrm{kg}$ for the mass flux equal to $\dot{m}=0.009 \mathrm{~kg} / \mathrm{s}$, so exergetic efficiency is equal to $\varepsilon=(130 \mathrm{~W}+1.6 \mathrm{~W}) / 1000 \mathrm{~W}=13.16 \%$ which is close to the photovoltaic efficiency: $\eta_{\mathrm{PV}}=130 \mathrm{~W} / 1000 \mathrm{~W}=$ $13 \%$.

In the case, when water is heated in the $\mathrm{PV} / \mathrm{T}$ system from $10^{\circ} \mathrm{C}$ to $55^{\circ} \mathrm{C}$ the better result may be obtained: $\Delta b_{w}=\Delta b_{f}=46129 \mathrm{~J} / \mathrm{kg}$ for the mass flux equal to $\dot{m}=$ $0.0042 \mathrm{~kg} / \mathrm{s}$, so exergetic efficiency is equal to $\varepsilon=(111 \mathrm{~W}+$ $195 \mathrm{~W}) / 1000 \mathrm{~W}=30.6 \%$, while the photovoltaic efficiency is smaller due to the higher temperature of the PV module: $\eta_{\mathrm{PV}}=0.13 \cdot\left(1-8 \cdot 10^{-3}(318-300)\right)=11.1 \%$.

Because in PV/T system applications the production of electricity is the main priority, it is necessary to operate the PV modules at low temperature, which diminishes the value of heat harvested. In this case the exergetic efficiency is very small.

\section{Conclusions}

The solar cells/modules photovoltaic efficiencies are in the range 13-15\% for STC conditions. For solar cells that are not cooled, working temperatures of $60-80^{\circ} \mathrm{C}$ are common and this corresponds to smaller electrical efficiencies: about $10 \%$. Integration of a photovoltaic solar module with a flat heat collector (PV/T system) in order to reduce the temperature of silicon solar cells has many advantages:

(i) increase of the electric output power,

(ii) improvement of conversion efficiency of solar cells,

(iii) heat transfer from the module to the cooling medium.

The relative increase in solar cells efficiency as the result of cooling is in order of $10-30 \%$.

The hybrid system generates electricity that has a much higher quantity than produced heat. Therefore it is very difficult to compare the $\mathrm{PV} / \mathrm{T}$ system with the customary thermal system.

It is impossible to obtain the maximum electric and thermal efficiency simultaneously - a kind of tradeoff is necessary. The most important parameters are the flow rate and the inlet temperature, since the cell temperature depends strongly on them. For the smallest values of the mass flow rates it is possible to obtain considerable increase of the cooling medium temperature, but the improvement of electric efficiency will be very small. Increasing the highquality output-electricity-leads to the lower quality of the heat (lower temperature of the medium).

In the present study the concept of exegetic efficiency analysis instead of overall energy efficiency or primaryenergy saving efficiency, used by other authors, was proposed for evaluation of the PV/T systems. These considerations are necessary to characterize the system for various applications. The exergy analysis of the hybrid system allows evaluating influence of every particular process on the efficiency of the system, eliminating the profitless components of the system, and identifying the maximum efficiency of the system.

\section{Nomenclature}

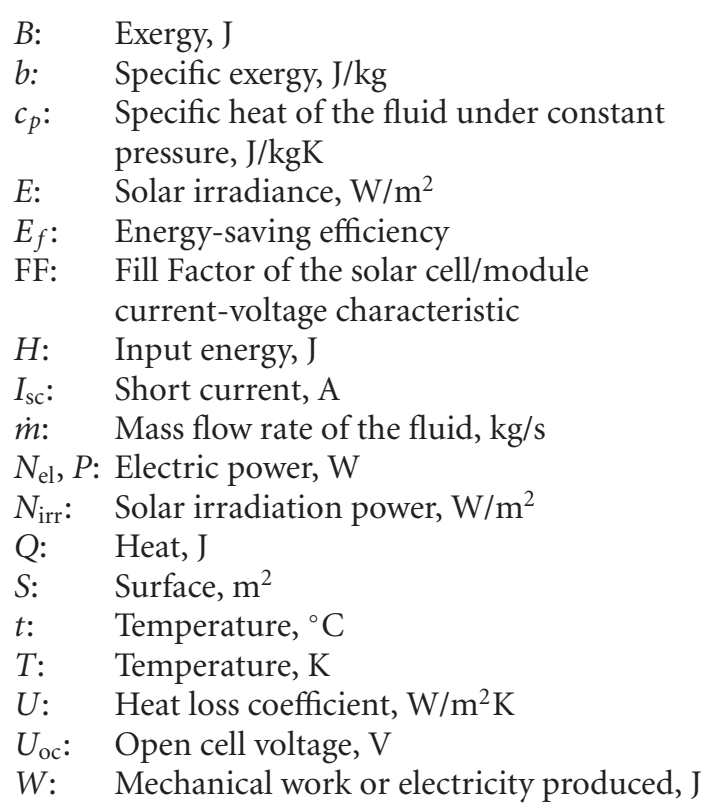

\section{Greek symbols}

$\beta$ : Efficiency temperature coefficient

$\varepsilon$ : Exergetic efficiency

$\eta_{\mathrm{el}}$ : Electric efficiency

$\eta_{T}$ : Thermal efficiency

\section{Subscripts}

$\begin{array}{ll}a: & \text { Ambient } \\ \text { av: } & \text { Average } \\ \mathrm{cm}: & \text { Cooling medium } \\ f: & \text { Physical } \\ m: & \text { Module } \\ \text { max: } & \text { Maximum } \\ \text { PV: } & \text { Photovoltaic } \\ \text { T: } & \text { Thermal } \\ w: & \text { Water }\end{array}$

\section{References}

[1] H. P. Garg and R. K. Agarwal, "Some aspects of a PV/T collector/forced circulation flat plate solar water heater with solar cells," Energy Conversion and Management, vol. 36, no. 2, pp. 87-99, 1995.

[2] J. Prakash, "Transient analysis of a photovoltaic-thermal solar collector for co-generation of electricity and hot air/water," Energy Conversion and Management, vol. 35, no. 11, pp. 967972, 1994.

[3] K. Sopian, K. S. Yigit, H. T. Liu, S. Kakaç, and T. N. Veziroglu, "Performance analysis of photovoltaic thermal air heaters," Energy Conversion and Management, vol. 37, no. 11, pp. 1657$1670,1996$.

[4] J. K. Tonui and Y. Tripanagnostopoulos, "Improved PV/T solar collectors with heat extraction by forced or natural air circulation," Renewable Energy, vol. 32, no. 4, pp. 623-637, 2007. 
[5] H. A. Zondag, D. W. de Vries, W. G. J. van Helden, R. J. C. van Zolingen, and A. A. van Steenhoven, "The thermal and electrical yield of a PV-thermal collector," Solar Energy, vol. 72, no. 2, pp. 113-128, 2002.

[6] Y. Tripanagnostopoulos, Th. Nousia, M. Souliotis, and P. Yianoulis, "Hybrid photovoltaic/thermal solar systems," Solar Energy, vol. 72, no. 3, pp. 217-234, 2002.

[7] E. Radziemska, "The effect of temperature on the power drop in crystalline silicon solar cells," Renewable Energy, vol. 28, no. 1, pp. 1-12, 2003.

[8] S. A. Kalogirou and Y. Tripanagnostopoulos, "Hybrid PV/T solar systems for domestic hot water and electricity production," Energy Conversion and Management, vol. 47, no. 18-19, pp. 3368-3382, 2006.

[9] B. Sandnes and J. Rekstad, "A photovoltaic/thermal (PV/T) collector with a polymer absorber plate. Experimental study and analytical model," Solar Energy, vol. 72, no. 1, pp. 63-73, 2002.

[10] PVTWINS' information, http://www.pvtwins.nl.

[11] T. Bergene and O. M. Løvvik, "Model calculations on a flatplate solar heat collector with integrated solar cells," Solar Energy, vol. 55, no. 6, pp. 453-462, 1995.

[12] E. Radziemska, "Thermal performance of Si and GaAs based solar cells and modules: a review," Progress in Energy and Combustion Science, vol. 29, no. 5, pp. 407-424, 2003.

[13] I. S. Ertesvåg, "Exergetic comparison of efficiency indicators for combined heat and power (CHP)," Energy, vol. 32, no. 11, pp. 2038-2050, 2007.

[14] B. J. Huang, T. H. Lin, W. C. Hung, and F. S. Sun, "Performance evaluation of solar photovoltaic/thermal systems," Solar Energy, vol. 70, no. 5, pp. 443-448, 2001.

[15] G. Tsatsaronis, "Definitions and nomenclature in exergy analysis and exergoeconomics," Energy, vol. 32, no. 4, pp. 249253, 2007.

[16] A. Bejan, G. Tsatsaronis, and M. Moran, Thermal Design and Optimization, John Wiley \& Sons, New York, NY, USA, 1996. 


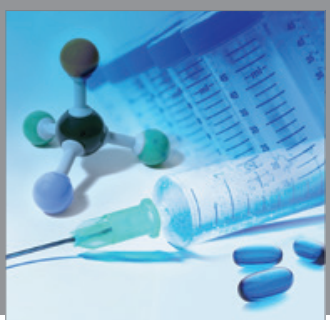

International Journal of

Medicinal Chemistry

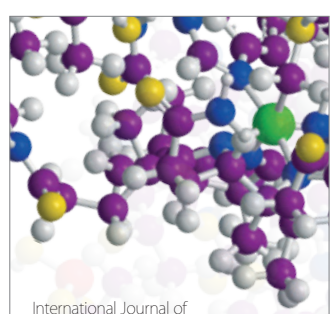

Carbohydrate Chemistry

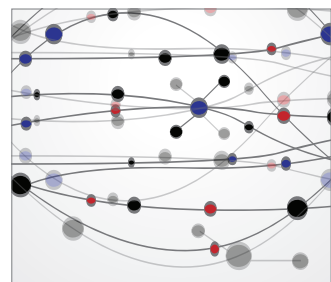

The Scientific World Journal
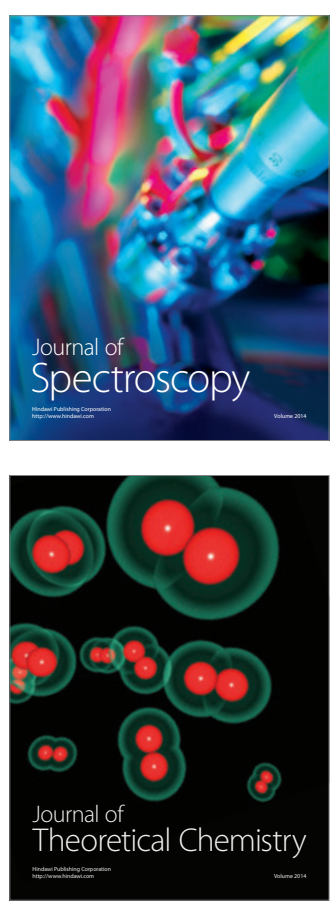
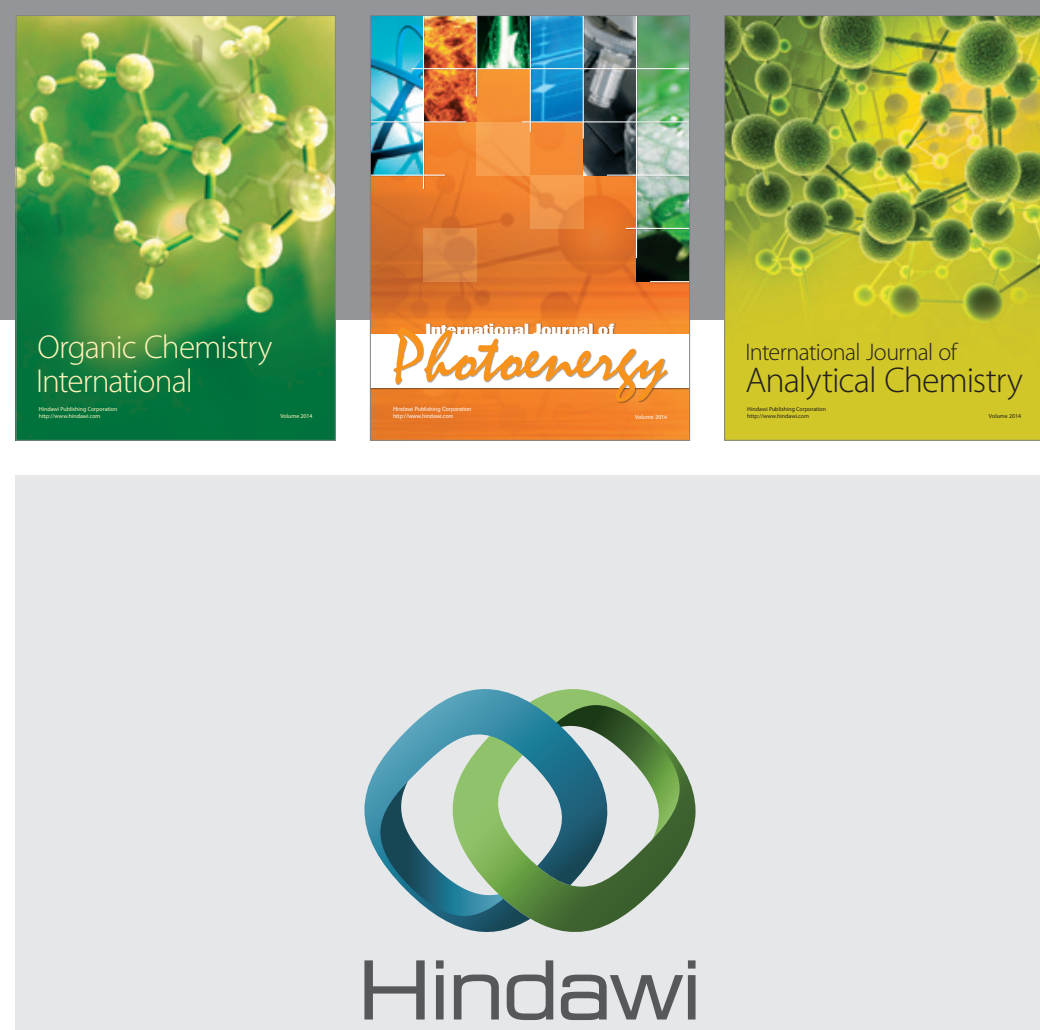

Submit your manuscripts at

http://www.hindawi.com
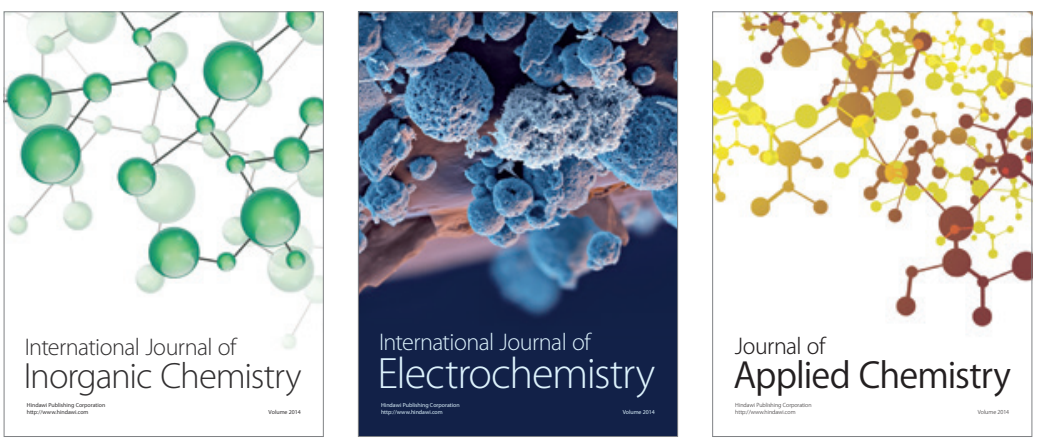

Journal of

Applied Chemistry
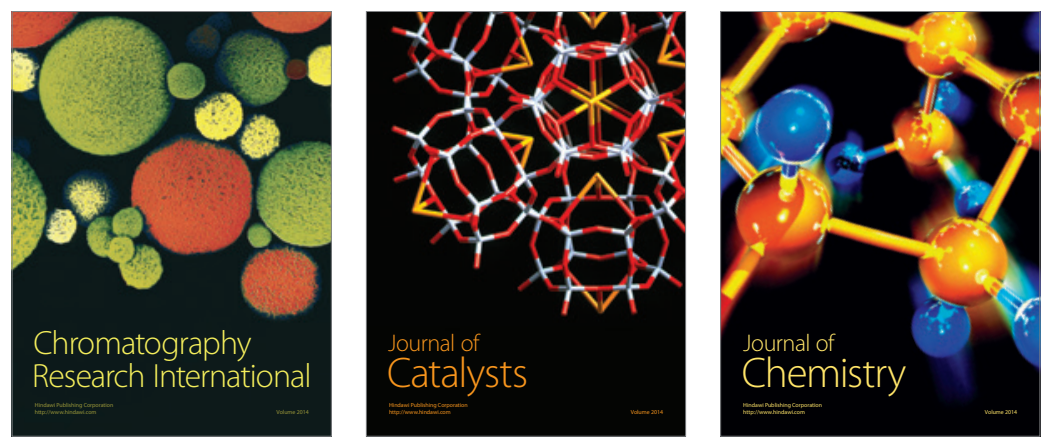
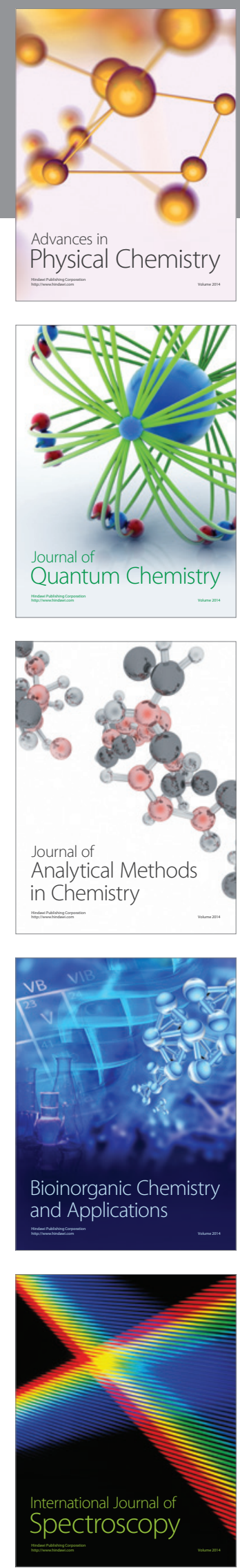